\title{
INDUSTRI FILM INDONESIA SEBAGAI BAGIAN DARI INDUSTRI KREATIF INDONESIA
}

\section{Idola Perdini Putri, Reni Nuraeni, Maylanny Christin, Mohamad Syahriar Sugandi}

Universitas Telkom Jalan Telekomunikasi No. 1, Terusan Buah Batu-Dayeuh Kolot, Bandung, Indonesia, 40257

idola_perdiniputri@yahoo.com

\begin{abstract}
Abstrak
Tulisan ini menjelaskan tentang industri film Indonesia pasca reformasi sebagai salah satu sub-sektor industri kreatif. Industri kreatif dianggap banyak memberikan sumbangsih positif terhadap pembangunan sebuah kota bahkan negara dalam hal peningkatan pasar dan ekonomi global. Industri kreatif memiliki potensi besar untuk meningkatkan ekonomi dan kualitas hidup masyarakat Indonesia. Industri film dunia sendiri mampu memperoleh pendapatan hingga $\$ 10,162,657,657$ (sekitar 980 triliun rupiah), dengan penjualan tiket mencapai 1.276.715.780 buah, dan jumlah penonton bioskop yang mencapai lebih dari 700 juta orang. Sementara di Indonesia menurut penelitian Oxford Economics, dengan mempertimbangkan transaksi langsung dan tidak langsung yang ditimbulkan, total kontribusi ekonomi Industri film dan televisi terhadap PDB pada 2010 mencapai USD 2,98 miliar atau 0,43 persen dari seluruh PDB nasional. Deskripsi industri film Indonesia menganalisis tiga subsektor industri film yaitu produksi, distribusi dan eksebisi dan menggambarkan bagaimana kondisi pada industri film nasional pada era pasca reformasi sejak industri film didapuk sebagai salah satu sub-sektor industri kreatif.
\end{abstract}

Kata Kunci: Industri film Indonesia, industri kreatif, film independen 


\section{Pendahuluan}

Sepanjang tahun proses pembuatan film berlangsung di seluruh dunia. Berbagai genre film diproduksi dengan menggunakan bermacam variasi teknologi dan teknik sinematik. Film kemudian menjadi cerminan budaya bangsa juga media representasi sebuah kondisi tatanan sosial suatu bangsa. Hal ini dikarenakan film adalah hasil kerja kolektif, yang dengan kata lain, proses pembuatan film pasti melibatkan kerja sejumlah unsur atau profesi, seperti: produser, sutradara, penulis skenario, penata kamera, penata artistik, penata musik, editor, pengisi dan penata suara, serta aktor-aktris.

Sejak awal abad ke-19, di tahun 1888, saat Thomas Alfa Edison menemukan mesin sinema pertama bernama kinematografi, industri perfilman dunia terus berkembang. Awalnya, produksi-produksi film Perancis menjadi motor kebangkitan film dunia, ditandai oleh film kolosal pertama hasil karya Charles Pathe. Namun, setelah perang dunia 1 usai, industri perfilman Hollywood merajai pasar perfilman dunia. Enam studio film terbesar dunia, lahir di Amerika Serikat, Warner Bros. Pictures (1923), Metro-Goldwyn-Meyer (1924), Radio-Keith-Orpheum (RKO, 1928), 20th Century Pictures Company (1933), Paramount Pictures (1935) dan termasuk diantaranya Walt Disney Pictures, yang menaungi Touchstone Picture, Pixar Animation Studio dan Marvels Studio.

Ribuan film diproduksi setiap tahun dan perkembangan industri film kini menjadi milik dunia tidak hanya Hollywood. India yang menjadi negara paling produktif dalam pembuatan film, menamakan industrinya dengan nama Bollywood -gabungan nama Bombay dan Hollywood. Sementara pada dunia yang lain, Nigeria pun mulai membangun industri film alternatif dengan nama Nollywood. Namun demikian, Cina merupakan negara yang disebutkan sebagai salah satu pasar film yang pertumbuhannya paling cepat diantara negara lainnya. Misalnya saja di minggu kedua Februari 2016 total pendapatan box office China mencapai 548 juta dolar AS, atau setara Rp 7,4 triliun, yang menurut pantauan The Hollywood Reporter, jumlah pendapatan tersebut melampaui rekor 
pendapatan box office Amerika Utara, saat Star Wars: The Force Awakens dirilis, dengan pendapatan terhitung dari 26 Desember sampai 1 Januari, hanya mencapai 529,6 juta dolar AS (Della, 2016). Film sendiri disamping sebagai komoditas ekonomi juga berfungsi sebagai sarana penerangan (entertainment), pendidikan (edukasi), dan hiburan (rekreasi). Di sisi lain dewasa ini dengan konvergensi teknologi dan perkembangan teknologi digital, industri film dunia telah menjadi bagian dari industri kreatif.

Film menjadi salah satu bidang industri kreatif karena memiliki potensi besar pada pengembangan ekonomi kreatif. Sheila Timothy, produser dari Lifelike Pictures sekaligus Ketua Asosiasi Produser Film Indonesia (Aprofi), mengatakan bahwa film adalah benda budaya yang punya nilai ekonomi, film terlihat seperti soft power tapi super power (Rulianto, 2013). Film dengan dua karakter bawaan, budaya dan ekonomi, yang tak bisa terpisahkan inilah yang membuat film jadi memiliki kekuatan besar. Salah satu contoh perwujudan paling nyata dan aktual adalah film-film blockbuster Hollywood yang memiliki nilai ekonomis tinggi (aktor-aktris terkenal, skala produksi besar, cerita menarik, efek visual ciamik, soundtrack dari para musisi tenar, dan sebagainya) serta penetrasi pasarnya yang amat agresi, namun, di sisi lain, film-film blockbuster Hollywood tersebut juga memuat nilainilai budaya (cara hidup, adat, nilai dan norma, ideologi, hingga budaya politik dan sebagainya) yang kemudian mampu menyelusup dengan baik ke benak pikiran para penontonnya dari negara lain (Rulianto, 2013). Kehadiran nilai-nilai budaya dalam film ini kerap dimanfaatkan Hollywood untuk memperlihatkan kekuatan dan upayanya untuk mendominasi kehidupan politik dan keamanan dunia.

Film sebagai produk budaya memang memili peran penting dalam penyampaian pesan budaya lokal. Seperti juga terjadi di Hollywood dan belahan dunia yang lain Indonesia sendiri pernah memanfaatkan kekuatan budaya dan ekonomi dalam film selama era kepemimpinan Soeharto dengan tujuan mengukuhkan kekuasaan Orde Baru selama 32 tahun. Sebut saja film G30S PKI dan Janur Kuning yang menceritakan kepemimpinan Soeharto yang digambarkan sebagai pahlawan Bangsa, tokoh pembela pribumi dan 
pemimpin yang adil. Kini, sejak era pemerintahan Soeharto berakhir, industri film Indonesia terus berkembang. Penggambaran akan budaya lokal dan pemanfaatan media film sebagai alat penyampai pesan baik politik dan budaya maupun sebagai alat penggiat ekonomi tetap muncul pada industri film Indonesia dewasa ini. Namun demikian variasi genre, produk dan jenis film menjadi lebih beragam dan bebas dalam kaitannya mengekspresikan ideologi pembuat film.

\section{Industri Kreatif Indonesia}

Ketertarikan terhadap industri kreatif berkembang tidak hanya diantara negaranegara maju, tetapi juga negara-negara berkembang dalam beberapa tahun terakhir. Ekonomi kreatif merupakan sebuah konsep yang menempatkan kreativitas dan pengetahuan sebagai asset utama dalam menggerakan ekonomi. Pesan besar yang ditawarkan ekonomi kreatif adalah pemanfaatan cadangan sumber daya yang bukan hanya terbarukan, bahkan tak terbatas, yaitu ide, talenta dan kreativitas (Tim Indonesia Design Power - Departemen Perdagangan, 2008: 1). Ekonomi kreatif dianggap banyak memberikan sumbangsih positif terhadap pembangunan sebuah kota bahkan negara dalam hal peningkatan pasar dan ekonomi global.

Jumlah negara yang mengaplikasikan industri kreatif secara signifikan menjadi lebih tinggi dan memberikan stabilitas yang lebih besar ke masa depan, dengan demikian, konsep industri kreatif telah berhasil diintegrasikan ke dalam agenda kebijakan baik negara maju dan berkembang. Pemerintah mulai mengembangkan secara spesifik strategi dan kebijakan untuk mempromosikan mereka. Industri kreatif menjadi salah satu sektor berkembang yang tercepat di dunia. Rata-rata pertumbuhan tahunan industri kreatif di dunia mencapai angka antara 5 dan 20\% (Simatupang et al., 2012). Dalam beberapa kasus, peningkatan pendapatan dari sektor industri kreatif, mencapai nomor lebih tinggi dari peningkatan ekonomi secara keseluruhan di negara yang bersangkutan. 
Beberapa negara terkenal karena sukses mereka dalam mengembangkan industri kreatif. Manchester Institute for Culture Populer (www.mmu.ac.uk/h-ss/mipc) telah mengidentifikasi inisiatif industri kreatif di kota-kota Barcelona (Spanyol), Goteburg (Denmark), Milan (Italia), Jämtland (Swedia), Tilburg (Belanda), Berlin (Jerman), Helsinki (Finlandia), dan Dublin (Irlandia) (Flew, 2002). Cunningham (2009) mengidentifikasi beberapa variasi pada "tema kreatif industri seperti yang telah melakukan perjalanan di seluruh dunia", dan poin ke penekanan yang berbeda-beda dan hasil di Amerika Serikat, Eropa, Asia, China, Australasia, dan global Selatan (Ashton, 2013). Sementara di Asia Timur, pemerintah Singapura dan Malaysia, adalah perintis dalam mengembangkan infrastruktur broadband jaringan melalui inisiatif Multimedia Super Corridor (MSC) dan 'Pulau Cerdas' (Flew, 2002).

Istilah industri kreatif muncul pada awal tahun 1990 di Australia dikemukakan oleh Howkins, sementara sarjana bisnis lainnya mengklaim bahwa industri terjadi di Inggris pada tahun 1997. Ekonomi kreatif diperkenalkan secara global oleh John Howkins melalui buku "The Creative Economy: How People Make Money from Ideas" di tahun 2001. Howkins menyadari lahirnya gelombang ekonomi baru berbasis kreativitas setelah melihat pada tahun 1997 Amerika Serikat menghasilkan produk-produk Hak Kekayaan Intelektual (HKI) senilai 414 Miliar Dollar yang menjadikan HKI ekspor nomor 1 Amerika Serikat. Howkins lalu dengan ringkas mendefinisikan ekonomi kreatif, sebagai:

"Kegiatan ekonomi dalam masyarakat yang menghabiskan sebagian besar waktunya untuk menghasilkan ide, tidak hanya melakukan hal-hal yang rutin dan berulang. Karena bagi masyarakat ini, menghasilkan ide merupakan hal yang harus dilakukan untuk kemajuan."

Sementara Studi Ekonomi Kreatif terbaru yang dilakukan United Nations Conference on Trade and Development (UNCTAD) pada tahun 2010 mendefinisikan Ekonomi Kreatif sebagai: "An evolving concept based on creative assets potentially generating economic growth and development." Dengan penjabaran lebih lanjut sebagai berikut: 
1. Mendorong peningkatan pendapatan, penciptaan pekerjaan, dan pendapatan ekspor sekaligus mempromosikan kepedulian sosial, keragaman budaya, dan pengembangan manusia.

2. Menyertakan aspek sosial, budaya, dan ekonomi dalam pengembangan teknologi, Hak Kekayaan Intelektual, dan pariwisata.

3. Kumpulan aktivitas ekonomi berbasiskan pengetahuan dengan dimensi pengembangan dan keterhubungan lintas sektoral pada level ekonomi mikro dan makro secara keseluruhan.

4. Suatu pilihan strategi pengembangan yang membutuhkan tindakan lintas kementerian dan kebijakan yang inovatif dan multidisiplin.

5. Di jantung Ekonomi Kreatif terdapat Industri Kreatif.

Terkait dengan popularitas industri kreatif, sekarang, definisi industri kreatif dilihat dari berbagai sudut pandang. UK Departemen Kebudayaan, Media dan Olahraga mendefinisikan industri kreatif sebagai industri-industri yang memiliki asal mereka dalam kreativitas individu, keterampilan dan bakat dan yang memiliki potensi kekayaan dan penciptaan lapangan kerja melalui generasi dan eksploitasi kekayaan intelektual (Carr, 2009; Cunningham, Potts, Hartley, \& Ormerod, 2005;. Durmaz et al, 2010; Terbang, 2002; Higgs \& Cunningham, 2008;. Simatupang et al, 2012). Serupa dengan itu, O'Connor (2009, p. 366) menunjukkan, bahwa "industri kreatif" dapat dipahami sebagai "pengelompokan khas ekonomi, kerangka kerja untuk conjoining jenis tertentu tenaga kerja intelektual atau artistik, atau hanya berbentuk sebuah kebijakan membangun "(Ashton, 2013). Oleh karena itu, kedua definisi menunjukkan kepada pengembangan modal manusia sebagai sumber daya terbatas dan kekayaan intelektual.

Dalam definisi lain, menurut Howkins industri kreatif didefinisikan sebagai definisi analitik baru dari komponen industri ekonomi di mana kreativitas merupakan masukan dan konten atau kekayaan intelektual adalah output (Potts \& Cunningham, 1998). la 
menyatakan bahwa istilah "industri kreatif" harus berlaku untuk setiap industri di mana "kekuatan kreativitas manusia adalah lebih besar dan di mana hasilnya adalah kekayaan intelektual (Galloway \& Dunlop, 2007). Howkins menggarisbawahi proses kreativitas dan kekayaan intelektual untuk menggambarkan industri kreatif. Di sisi lain, perspektif yang berbeda disebutkan oleh Scott (2000) yang menjelaskan industri kreatif yang ditandai dengan output produk dikomersialkan dengan konten estetika dan simbolis tinggi, mencerminkan kecenderungan produksi kreatif menjadi komoditas semakin tinggi, sementara komoditas kreativitas sendiri menjadi semakin diinvestasikan dengan nilai simbolik (Chen, 2012). Scoot menunjukkan produk kreatif sebagai penanda industri kreatif.

Definisi lingkup industri kreatif umumnya termasuk produk kreatif (yaitu seni pertunjukan, seni visual, kerajinan, desain, desainer fashion, film, software rekreasi interaktif, musik, dan TV dan radio) dan jasa kreatif (yaitu periklanan, arsitektur, penerbitan, fasilitas budaya, dan perangkat lunak dan layanan komputer) (Chen, 2012;. Simatupang et al, 2012). Seiring dengan perkembangan teknologi digital, sub sektor industri kreatif menambahkan spesifikasi produk dengan produk konten digital. konten digital dan aplikasi yang dihasilkan oleh industri kreatif termasuk output dari industri game komputer, situs web, seni video digital dan film yang digital dan produksi televisi yang meliputi teks, grafik, efek khusus, animasi dan pasca-produksi, di bidang media baru, musik, arsitektur dan desain, dan pendidikan dan kesehatan (DCITA 2001 seperti yang disebutkan oleh Flew, 2002). Meskipun sub sektor industri kreatif dikategorikan oleh sarjana, sub sektor berkembang sesuai kebutuhan masing-masing negara. Beberapa sektor mengakomodasi nilai-nilai budaya lebih dari sektor lain. nilai-nilai budaya ini membuat industri kreatif di penting menjaga identitas lokal.

Di Indonesia sendiri, dalam Cetak Biru Pengembangan Ekonomi Kreatif Nasional 20092015 (2008), ekonomi kreatif didefinisikan sebagai: “Era baru ekonomi setelah ekonomi pertanian, ekonomi industri, dan ekonomi informasi, yang mengintensifkan informasi dan kreativitas dengan mengandalkan ide dan pengetahuan dari sumber daya manusia sebagai 
faktor produksi utama dalam kegiatan ekonominya." Sedangkan definisi Industri Kreatif di Indonesia seperti yang tertulis dalam Cetak Biru Pengembangan Ekonomi Kreatif Nasional 2009-2015 (2008) adalah: “Industri yang berasal dari pemanfaatan kreativitas, ketrampilan serta bakat individu untuk menciptakan kesejahteraan serta lapangan pekerjaan melalui penciptaan dan pemanfaatan daya kreasi dan daya cipta individu tersebut." Ekonomi kreatif menyumbang Produk Domestik Bruto (PDB) 7,38\% dari total kontribusi ekonomi nasional pada 2015. Sepanjang periode 2010-2015, produk domestik bruto (PDB) ekonomi kreatif naik dari Rp525,96 triliun menjadi Rp852,24 triliun (Margrit, 2016). Sementara, berkaitan dengan angkatan kerja yang terserap, ekonomi kreatif menyumbang 12 juta orang pada total angkatan kerja nasional yang sebesar. Angka-angka ini menunjukkan bahwa kontribusi industri kreatif Indonesia pada PDB dan jumlah tenaga kerja terserap terlihat signifikan. Ekonomi kreatif memiliki potensi besar untuk meningkatkan ekonomi dan kualitas hidup masyarakat Indonesia.

Departemen Perdagangan Republik Indonesia memetakan 15 bidang ekonomi kreatif -tidak jauh berbeda dengan pemetaan pada negara lain maupun organisasi dunia lainnya. Pada tahun 2007, Departemen Perdagangan Republik Indonesia, mendefinisikan industri kreatif sebagai industri yang berasal dari pemanfaatan kreativitas, ketrampilan serta bakat individu untuk menciptakan kesejahteraan serta lapangan pekerjaan melalui penciptaan dan pemanfaatan daya kreasi dan daya cipta individu tersebut (Tim Indonesia Design Power

Departemen Perdagangan, 2008: 4). Adapun 15 bidang ekonomi kreatif Indonesia adalah periklanan, arsitektur, pasar barang seni, kerajinan, desain, fesyen, video, film dan fotografi, permainan interaktif, musik, seni pertunjukkan, penerbitan dan percetakan, layanan komputer dan peranti lunak, televisi dan radio, riset dan pengembangan, dan kuliner. Masing-masing dari sub-sektor industri kreatif ini

Konten budaya pada produk industri kreatif adalah cara-cara baru untuk negara dan kota untuk menjadi lebih kompetitif di era ekonomi global. Masyarakat yang mengkonsumsi lebih banyak budaya dan pengalaman dalam berbagai bentuk kreatif, itu berdampak pada 
tingginya tingkat pertumbuhan penjualan produk budaya (Nielsen, 2009). Ekonomi pengalaman dengan identitas budaya dan pengaruh sosial sebagai komponen penting adalah konsumsi ekonomi baru (Cunningham et al., 2005). Berdasarkan laporan keuangan tersebut industri kreatif memiliki peran dalam menempa identitas nasional di dalamnya berfungsi dalam mempertahankan budaya lokal. Budaya merupakan bibit citra dan identitas, lokal bantuan budaya masyarakat untuk membentuk identitas-baik individu dan kolektif (Nielsen, 2009). Dalam bidang industri kreatif budaya ini sering dinyatakan sebagai bentuk gaya hidup yang pada gilirannya dibentuk oleh karya seni (film, musik, teater, dIl).

Dalam globalisasi, media massa menjadi pihak penting untuk gagasan identitas nasional. Namun, beberapa sarjana juga mengatakan bahwa menurut teori Robertson, globalisasi tidak dapat diartikan sebagai penciptaan budaya global, bukan ada kesempatan bagi berbagai budaya berinteraksi pada skala global (Ashton, 2013). Beberapa ahli bahkan melangkah lebih jauh dalam menekankan pentingnya media dan mempertimbangkan media massa sebagai pemain utama dalam proses globalisasi. Rap (1997) mengatakan bahwa mereka menganggap media bukan hanya sebagai instrumen belaka, bukan sebagai identitas dalam dirinya sendiri, yang bisa bersaing dengan pemerintah nasional yang berkaitan dengan kekuasaan dan pengaruhnya untuk mengubah sifat dan esensi dari masyarakat manusia (Ashton, 2013). Film sebagai media massa bisa menjadi alat untuk memperkuat konten lokal dalam bentuk produk industri kreatif.

\section{Industri Film Indonesia Sebagai Salah Satu Sub-sektor Industri Kreatif Indonesia}

Film pertama di Indonesia, diputar pada tahun 1900 di Batavia, sejak saat itu film semakin digemari masyarakat Indonesia dan menjadi salah satu penghiburan populer di Indonesia. Bioskop-bioskop mulai bermunculan di kota-kota besar di Indonesia, tercatat 300 bioskop berdiri di Indonesia sepanjang tahun 1900 hingga 1942. Sementara itu, di tahun 1926 Indonesia memproduksi film pertama berjudul Loetoeng Kasaroeng, diproduksi oleh NV Java Film Company. Hingga hari kemerdekaan industri film Indonesia digawangi oleh 
pada pekerja asing di Indonesia -sebagian besar warga negara Eropa dan Cina, sementara pribumi memegang hanya sebagian kecil peran. Barulah pada tahun 1950 industri film Indonesia dipegang oleh pribumi, dimana Usmar Ismail memproduksi film Darah dan Doa. Pada tahun 1950 inilah yang diakui sebagai tonggak awal berdirinya industri film Indonesia. Hari pertama pengambilan gambar pembuatan film Darah dan Doa diresmikan sebagai hari film nasional oleh pemerintahan Orde Baru. Demikian, secara resmi industri film Indonesia dipercaya barulah dimulai pada tahun 1950.

Sekarang lebih dari 67 tahun setelahnya, industri film Indonesia masih terus mengalami masa naik dan turun dalam perkembangannya. Pernah mengalami masa kejayaan di era tahun 1970-an hingga kemudian masa kemunduran bahkan dianggap nyaris mati di era tahun 1990-an, industri film Indonesia dipengaruhi oleh berbagai faktor. Industri film Indonesia di tahun 2006, menyumbang sebesar 0,24\% (sekitar 250 miliar rupiah) pada kontribusi PDB (Tim Indonesia Design Power-Departemen Perdagangan, 2008: 10). Di sisi lain, masih di tahun yang sama, subsektor industri kreatif film, video dan fotografi memiliki produktifitas tenaga kerja di atas rata-rata dengan Rp 53,163 juta/pekerja pertahun (Tim Indonesia Design Power - Departemen Perdagangan, 2008: 13). Meningkat pada tahuntahun berikutnya berdasarkan studi yang dilaksanakan lembaga konsultan dan penelitian Oxford Economics, dengan mempertimbangkan transaksi langsung dan tidak langsung yang ditimbulkan, total kontribusi ekonomi Industri film dan televisi terhadap PDB pada 2010 mencapai USD 2,98 miliar atau 0,43 persen dari seluruh PDB Nasional. Angka ini menunjukkan peningkatan signifikan dari hanya sebesar 0,24\% di tahun 2006 . Sementara di tahun 2012 kontribusi sebesar film dan televisi industri sebesar USD845,1 juta kepada perekonomian negara dan mampu menciptakan 191 ribu lapangan pekerjaan.

Salah satu hal yang unik dari keberadaan industri film Indonesia adalah bahwa industri ini dominan dipengaruhi oleh kebijakan pemerintah terkait dengan industri film pada masa yang bersangkutan. Selain itu, perkembangan industri film Indonesia pun dipengaruhi oleh situasi ekonomi, politik dan perkembangan teknologi di masyarakat. Industri film Indonesia 
pada dua dekade terakhir ini memang menunjukkan perkembangan yang signifikan dibandingkan dengan pada era pemerintahan sebelumnya, terlebih lagi setelah di tahun 2005, ketika film disertakan sebagai salah satu sub sektor industri kreatif Indonesia. Hal ini menunjukkan bahwa film nasional tidak lagi dianggap hanya sebagai alat politik dan ekonomi, namun juga sebagai budaya. Film dapat dijelaskan melalui rantai manajemen, produk dan regulasi yang terkait dengan industri.

Rantai manajemen industri film Indonesia terdiri dari rantai produksi, distribusi dan eksebisi. Rantai produksi merupakan tahapan mulai dari pencarian dana/investasi hingga film siap ditonton, pada rantai produksi terdapat proses kreatif dari pembuatan film, termasuk dalam rantai produksi adalah semua kru, perusahaan pembiayaan/investor, rumah produksi, perusahaan penyewaan alat, dan post-production house yang terlibat dalam pembuatan film (Effendy, 2008: 2). Sementara rantai distribusi film adalah sebuah "seni yang tak tampak", karena sepenuhnya berjalan dibelakang layar, jauh dari hiruk pikuk produksi dan sorotan publik di tahap eksibisi (Sasono et.al., 2011: 191). Perusahaan distribusi film atau distributor memainkan peran utama dalam menyalurkan film dari produsen ke jaringan bioskop, televisi dan home video (DVD dan VCD) (Effendy, 2008: 2). Sedangkan eksibisi adalah muara dari rangkaian pengelolaan pasokan (supply chain management), dimana produk film dikonsumsi oleh penonton dalam berbagai outlet berbeda seperti pertunjukkan di gedung bioskop dalam negeri (juga luar negeri), video di rumah, televisi (kabel dan terestial) (Sasono et.al., 2011: 275). Rantai ekshibisi biasanya dipegang oleh kelompok-kelompok bioskop dengan ribuan layarnya yang menjadi ujung tombak agar output rantai produksi dapat dinikmati oleh penikmat film bioskop (Effendy, 2008: 2).

Rantai produksi film di Indonesia melihat dari elemen sumber pendanaan/permodalan yaitu sponsored film, built-in, cross-promotion, TV terrestrial, investor pribadi dan co-production yang termasuk ke dalam jenis pendanaan komersial. Sementara pada rantai distribusi industri film di Indonesia dewasa hanya ada dua entitas 
yang bermain dalam industri film, yaitu produser dan importir -keduanya dihitung sebagai pemilik film - dan yang kedua adalah bioskop. Sedangkan untuk rantai eksibisi, jaringan kelompok 21 yang merupakan distributor dan importir juga memegang dominasi atas ruang eksibisi -dalam hal ini bioskop komersial di Indonesia selama puluhan tahun terakhir, baru kemudian muncul BlitzMegaplex di tahun 2006 dan Cinemaxx pada 2012 sebagai kompetitor.

Dengan film sebagai bagian dari ekonomi kreatif, implikasinya, film tentunya menarik minat para pemodal besar untuk terlibat dalam industri sebagai usaha mendapatkan keuntungan dari bisnis perfilman dunia (Putri, 2013). Indie label dan major label kemudian muncul dalam industri mewakili tipe film dengan beberapa karakteristik yang berbeda. Kedua konsep ini selalu menjadi dua fenomena yang berbeda, major label akan memproduksi film-film arus utama yang menghasilkan keuntungan semata, sementara indie label memproduksi film-film yang lebih idealis. Jika film arus utama merupakan film dimana pendanaannya membutuhkan angka besar yang selalu dihitung biaya produksi dengan segala keuntungan dan kerugiannya, maka film independen diasumsikan sebagai film yang dibuat tidak semata-mata mengandalkan pendanaan yang besar, lebih mengutamakan materi atau skenario filmnya sendiri. Dengan demikian industri film Indonesia terbentuk dari produksi film mainstream, produksi film-film independen, mata rantai bioskop nasional, rumah produksi film, komunitas-komunitas film independen dan festival-festival film independen.

Gambar dibawah ini menjelaskan industri film Indonesia yang dibagi menjadi industri film mainstream dan film independen Indonesia dilihat dari ketiga rantai tersebut.

\section{Gambar 1}

Industri Film Indonesia 


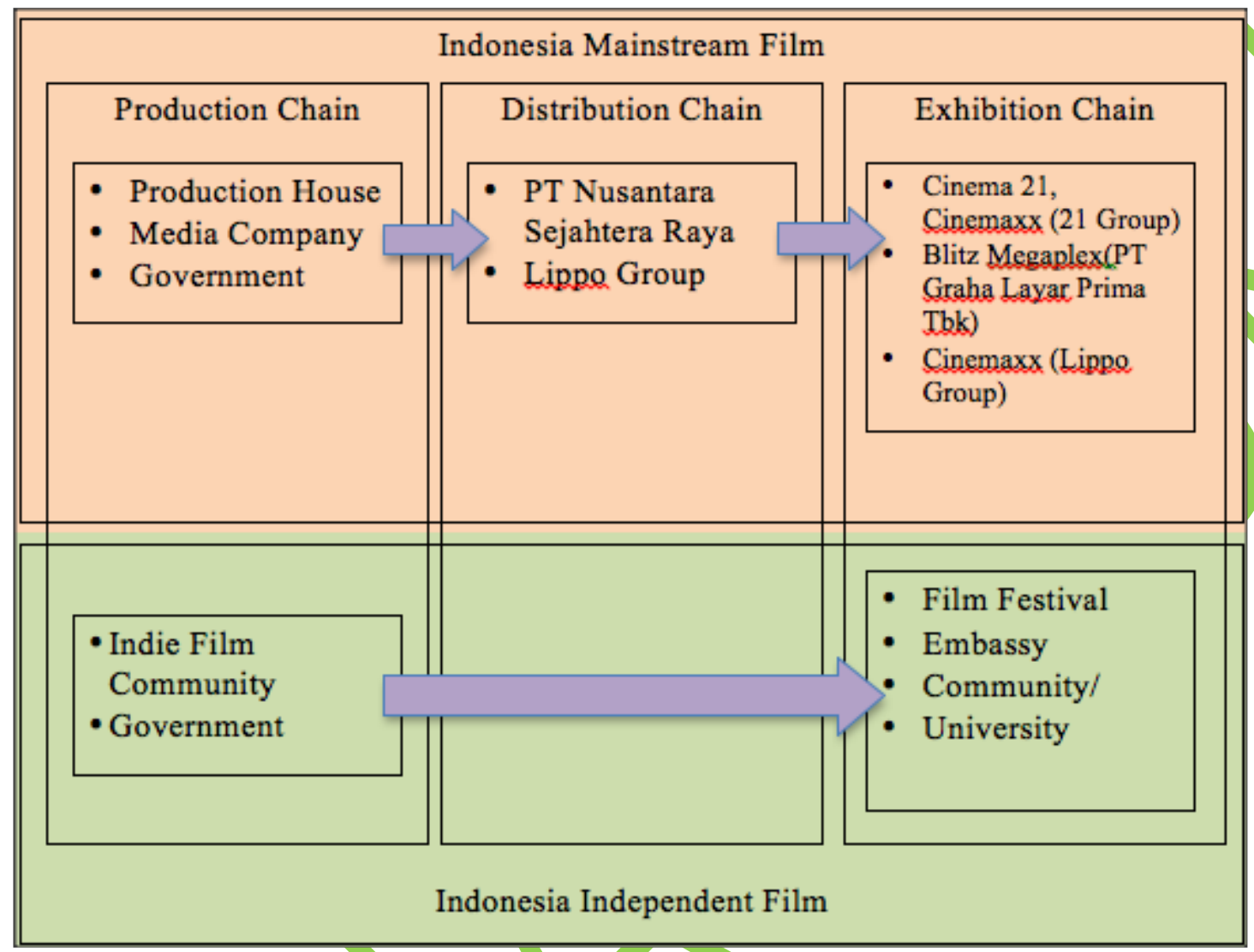

Dapat dilihat bahwa dari gambar tersebut film industri Indonesia termasuk ke dalam sebuah sistem industri oligopoli, dimana hanya terdapat beberapa pemain pada rantai film tertentu, bahkan hanya satu pemain pada rantai film yang lain. Industri film mainstream Indonesia masih didominasi nama lama di industri yang sudah ada sejak era kepemimpinan Soeharto. Sementara film independen Indonesia didominasi oleh komunitas-komunitas film yang secara swadaya mengembangkan film indepeden menjadi salah satu alternatif tontonan berkualitas bagi rakyat Indonesia. Film independen juga digawangi oleh sineassineas muda kreatif yang idealis dan mau beresiko membuat film independen yang seringkali tidak menarik secara komersial.

Film Independen dalam Industri Film Indonesia 
Sebagaimana di belahan dunia yang lain, industri film Indonesia pun mengalami euforia semangat membuat film do-it-yourself atau kemudian lebih sering disamakan dengan istilah film independen. Di Indonesia, terminologi film independen sering kali dihubungkan dengan film pendek, di sisi lain, film independen juga tidak selalu berdurasi pendek, demikian dengan kata lain, terdapat perbedaan mendasar antara film pendek dan film independen (Putri, 2013). Jika melihat pada karakteristik rantai manajemen, genre film dan regulasi dari independen film, Indonesia independen film menjadi lebih mudah diidentifikasi berdasarkan pada ruang eksebisi yang dilakukan, sumber anggaran serta anggaran yang diperlukan pada pembuatan film. Film independen merupakan film murah yang dibuat dengan anggaran di bawah 1 milyar rupiah, mendapatkan pendanaan nonkomersial yang secara umum bisa didapat dari lembaga donor, lembaga endowment film, perseorangan dengan logika pendanaan non-komersial, atau program Corporate Social Responsibility perusahaan, film independen juga didefinisikan sebagai film yang menggunakan eksibisi alternatif dan film-film yang ikut serta pada ajang-ajang festival film (Putri, 2013). Di lain pihak film independen pun harus mengangkat tema muatan lokal/budaya daerah, non-komersial, mencerminkan kodisi aktual masyarakat atau bahkan memberikan kritik pada kondisi bangsa, serta mewakili semangat perubahan.

Kejatuhan rezim Presiden Soeharto (1966-1998) pada Mei 1998 menjadi momentum bangkitnya industri film Indonesia secara umum, dan independen film secara khusus. Hal ini disebabkan oleh film Kuldesak yang secara kategori dapat dilabeli sebagai film independen yang disebut-sebut memberikan angin perubahan pada industri film Indonesia. Kuldesak (Riri Riza et al., 1997) berhasil masuk jaringan bioskop 21 Cineplex padahal film ini dibuat tanpa mendaftarkan rencana produksi film tersebut di Deppen dan para sutradaranya pun belum memperoleh keanggotaan wajib di instansi yang sama (yang mengharuskan sutradara menjadi asisten sutradara minimal lima kali; Heeren, 2012, h. 21 dalam Putri 2013). Karenanya, Kuldesak lalu dilabeli pers sebagai 'film independen' dan awal dari kembali menggeliatnya industri film Indonesia. Film ini dibuat dengan dana yang 
minim sejumlah 600 juta rupiah, diluar dana promosi yang mencapai 150-200 juta rupiah (semua sutradara dan pemain tak dibayar termasuk penata musik), namun Kudesak berhasil menghadirkan 130,000 penonton dari 10,000 penonton yang ditargetkan (Putri, 2013).

Film independen Indonesia terus berkembang, salah satu penanda yang paling signifikan adalah munculnya berbagai komunitas film independen dan penyelenggraan festival film baik skala nasional maupun internasional. Semakin tahun komunitas film independen terus bertambah dan produktif menghasilkan film yang mampu meraih berbagai penghargaan nasional dan internasional. Sejak tahun 1999 hingga sekarang tercatat puluhan festival diselenggarakn oleh penggiat film independen Indonesia.

Pada tahun 1999, 2000, 2001, 2002, 2006, 2007, 2008, 2009 dan 2010 misalnya Festival Film Video Independen (FFVII) yang kemudian berganti nama menjadi Festival Film Pendek Konfiden pada tahun 2006 diselenggarakan. Di tahun yang sama, 1999, JiFFest (Jakarta International Film Festival) digelar untuk pertama kalinya, JiFFest tidak pernah absen dari tahun 1999 hingga 2010. Masih pada tahun yang sama, diselenggarakan pula Europe on Screen oleh Pusat budaya Eropa, lembaga Eropa dan Kedutaan Besar Eropa. Festival ini pada awalnya diselenggarakan dengan nama European Film Festival (1999 dan 2003) dengan menjadi bagian dari JiFFest (2004, 2005 dan 2006). Kemudian festival tersebut menggunakan nama Europe on Screen sejak 2007 dengan diselenggarakan secara mandiri (Putri, 2013). Festival lainnya adalah OK. Video - Jakarta International Video Festival (sekarang bernama OK. Video: Jakarta International Video Festival) yang diselenggarakan oleh Ruang Rupa di Jakarta. Festival-festival lainnya diantaranya Festival Film Animasi Indonesia, Q! Film Festival Jakarta, Festival Film Dokumenter Yogyakarta, HelloFest Jakarta dan iNAFF (Indonesia International Fantastic Film Festival), Festival Film Dokumenter (FFD) Yogyakarta, Q! Film Festival, iNAFF, Jogja-NETPAC Asian Film Festival (JAFF), sebuah festival film internasional yang diselenggarakan oleh JAFF bekerjasama dengan NETPAC (Network for The Promotion of Asian Cinema) dan festival-festival berskala nasional yang diselenggarakan oleh komunitas film lokal di kota-kota tertentu, seperti Festival Film 
Purbalingga, Festival Film Solo, Malang Film Festival, Bali Documentary Film Festival, Festival Film Cianjur, Golden Lens-International Documentary Film Festival, Festival Film Pelajar (Putri, 2013).

Kondisi Indonesia yang mengalami perubahan dalam hal politik maupun ekonomi berakibat pada terbentuknya film independen Indonesia di masa sekarang ini. Film independen Indonesia juga dijelaskan oleh tiga rantai film industri, rantai produksi, distribusi dan eksibisi. Berbeda dengan industri film mainstream rantai tersebut dikelola secara swadaya oleh komunitas independen. Tidak heran jika pada akhirnya film independen Indonesia dianggap dapat lebih mampu merepresentasikan identitas budaya Indonesia. Jika pada masa Orde Baru, sinema independen Indonesia diwakili oleh film pinggiran yang tidak tayang di jaringan bioskop film komersil namun berjaya pada festival film internasional. Kini, sinema independen Indonesia juga melibatkan film-film yang mampu tayang di jaringan bioskop arus utama dan diproduksi oleh sineas-sineas yang terlibat di industri film arus utama. Hal ini berakibat pada terlibatnya sinema independen Indonesia sebagai bagian tak terpisahkan pada industri film nasional.

\section{Kesimpulan}

Industri film Indonesia sebagai bagian dari sub-sektor industri kreatif dapat dipetakan melalui konsep rantai manajemen yang terdiri dari rantai produksi, distribusi dan eksibisi. Rantai produksi film di Indonesia melihat dari elemen sumber pendanaan/permodalan yaitu sponsored film, built-in, cross-promotion, TV terrestrial, investor pribadi dan coproduction yang termasuk ke dalam jenis pendanaan komersial. Sementara pendanaan melalui lembaga donor, lembaga endowment film, perseorangan, customer relationship management, lembaga pemerintah dan quasi-pemerintah merupakan jenis pendanaan non-komersial. Sedangkan komponen pembentuk lainnya, dalam rantai produksi sebuah industri film adalah teknologi yang digunakan. Aspek tekologi dalam pembuatan film mencakup tata gambar, tata suara, editing, dan finishing. 
Sementara pada rantai distribusi industri film di Indonesia dewasa hanya ada dua entitas yang bermain dalam industri film, yaitu produser dan importir -keduanya dihitung sebagai pemilik film - dan yang kedua adalah bioskop. Bergantung pada kebijakan pemerintah yang berlaku, secara garis besar, ciri khas industri distribusi film di Indonesia adalah: adanya pengelompokan para pelaku industri yang diatur oleh negara sebagai bagian dari mekanisme korporatisme-negara; dan kondisi pasar yang kurang transparan. Sedangkan untuk rantai eksibisi, jaringan kelompok 21 yang merupakan distributor dan importir juga memegang dominasi atas ruang eksibisi -dalam hal ini bioskop komersial di Indonesia selama puluhan tahun terakhir, baru kemudian muncul BlitzMegaplex di tahun 2006 sebagai kompetitor. Selain dua bioskop komersial tersebut, ruang eksibisi alternatif muncul di Indonesia pada pusat-pusat kebudayaan dan pemerintahan.

Berbeda pada masa Orde Baru, sinema independen Indonesia diwakili oleh film pinggiran yang tidak tayang di jaringan bioskop film komersil namun berjaya pada festival film internasional. Sinema independen pasca Reformasi, memiliki bentuk yang lebih berkembang. Kini, sinema independen Indonesia juga melibatkan film-film yang mampu tayang di jaringan bioskop arus utama dan diproduksi oleh sineas-sineas yang terlibat di industri film arus utama. Hal ini berakibat pada terlibatnya sinema independen Indonesia sebagai bagian tak terpisahkan pada industri film nasional. 


\section{DAFTAR PUSTAKA}

Ashton, D. (2013). Media work and the creative industries Identity work, and professionalism. http://doi.org/10.1108/00400911111159494

Baskin, Askurifai. (2002). Peranan Perkembangan Film Indie terhadap Bangkitnya Film Nasional. Jurnal Komunikasi Mediator. Bandung: Universitas Islam Bandung.

Chen, C. (2012). A multiple criteria evaluation of creative industries for the cultural creativity centre in Taiwan. http://doi.org/10.1108/13552550910983031

Cunningham, S., Potts, J., Hartley, J., \& Ormerod, P. (2005). Social network markets : A new definition of the creative industries, 1-26.

Effendy, Heru. (2008). Industri Perfilman Indonesia: Sebuah Kajian. Jakarta: Erlangga.

Flew, T. (2002). Beyond ad hocery : Defining Creative Industries, 1-30.

Galloway, S., \& Dunlop, S. (2007). A Critique of Definitions of the Cultural and Creative Industries in Public Policy. International Journal of Cultural Policy, 13(1), 17-31. http://doi.org/10.1080/10286630701201657

Nielsén, T. (2009). THE CREATIVE INDUSTRIES - IMPLICATIONS FOR, (May), 1-21.

Potts, J., \& Cunningham, S. (1998). Four models of the creative industries.

Putri, Idola Perdini. (2013). Mendefinisikan Ulang Film Indie: Deskripsi Perkembangan Sinema Independen Indonesia. Jurnal Komunikasi Indonesia. Universitas Indonesia: Jakarta.

Sasono, Eric et. al.. (2011). Menjegal Film Indonesia: Pemetaan Ekonomi Politik Industri Film Indonesia. Jakarta: Rumah Film Indonesia \& Yayasan Tifa.

Simatupang, T. M., Rustiadi, S., \& Situmorang, D. B. M. (2012). Chapter 5 Enhancing the Competitiveness of the Creative Services Sector in Indonesia, (March), 173-270.

\section{Laman Daring}

Della, Mia Vita. (2016). Seminggu Raup Rp 7 Triliun, China Patahkan Rekor Box Office Dunia. Mutila.com. Diakses pada 2 Maret 2016 di http://www.muvila.com/film/artikel/seminggu-raup-rp-7-triliun-china-patahkan-rekorbox-office-dunia-160218z.html. 
Rulianto, Angga. (2015). Kekuatan Dahsyat Film: Budaya dan Ekonomi. Mutila.co. Diakses pada 1 Maret 2016 di http://www.muvila.com/film/artikel/kekuatan-dahsyat-filmbudaya-dan-ekonomi-150907p.html.

Margrit, Annisa. (2016). Kontribusi Ekonomi Kreatif Mulai Aktif. Koran Bisnis.com. Diakses pada 2 Maret 2016 di http://koran.bisnis.com/read/20161209/430/610663/kontribusiekonomi-kreatif-mulai-aktif 